\title{
The maternity ward of a teaching hospital: reconfiguration of maternal-child nursing care
}

\author{
Maternidade de um hospital-escola: reconfiguração da assistência de enfermagem materno infantil \\ Maternidad de un hospital-escuela: reconfiguración de la asistencia de enfermería materno-infantil
}

\section{Mônica Barros de Pontes', Tânia Cristina Franco Santos", Maria Angélica de Almeida Peres", Antonio José de Almeida Filho"}

' Universidade Federal do Espírito Santo. Vitória, Espírito Santo, Brazil.

" Universidade Federal do Rio de Janeiro, Escola de Enfermagem Anna Nery. Rio de Janeiro, Brazil.

\section{How to cite this article:}

Pontes MB, Santos TCF, Peres MAA, Almeida Filho AJ. The maternity ward of a teaching hospital: reconfiguration of maternal-child nursing care. Rev Bras Enferm [Internet]. 2018;71(Suppl 3):1265-72.

[Thematic Issue: Health of woman and child] DOI: http://dx.doi.org/10.1590/0034-7167-2016-0585

\section{Submission: 11-17-2016 Approval: 07-25-2017}

\section{ABSTRACT}

Objective: to analyze the strategies used by nurses and nurse professors for a better position in the maternity ward of the teaching hospital of the Universidade Federal do Espírito Santo. Method: this is a social-historical study with a qualitative approach. The primary sources were written documents, such as official letters, memos, ordinances, standards and routines of the hospital; photographic material; and oral testimonies from seven participants. The interviews were performed using a semistructured questionnaire, with questions regarding the adaptation from a sanatorium to a teaching hospital, the challenges faced, and the strategies adopted by the nursing department. Results: the results allowed us to understand the close link between the maternity ward and the nursing course of the Universidade Federal do Espírito Santo, which created a differentiated nursing care that integrated training and care with a broader and humanized look. Final considerations: the actions of the nurses were recognized and gave them professional visibility, influencing a new form of care in the maternity ward.

Descriptors: History of Nursing; Nursing Care; Maternity Ward; Teaching; Postpartum Period.

\section{RESUMO}

Objetivo: analisar as estratégias usadas pelas enfermeiras assistenciais e enfermeiras docentes por uma melhor posição na maternidade do hospital-escola da Universidade Federal do Espírito Santo. Método: estudo de natureza histórico-social com abordagem qualitativa. As fontes primárias constituíram-se de documentos escritos, como ofícios, memorandos, portarias, normas e rotinas hospitalares; material fotográfico; e depoimentos orais de sete participantes. A entrevista foi orientada por roteiro semiestruturado com questões sobre a adaptação do sanatório para hospital-escola, os desafios enfrentados e as estratégias adotadas pela enfermagem. Resultados: permitiram entender a estreita vinculação da maternidade com o curso de enfermagem da Universidade Federal do Espírito Santo, o que determinava uma assistência de enfermagem diferenciada, a qual integrava ensino e assistência com um olhar mais amplo e humanizado. Considerações finais: as ações das enfermeiras foram reconhecidas e geraram visibilidade profissional, influenciando uma nova forma de cuidar na maternidade.

Descritores: História da Enfermagem; Cuidados de Enfermagem; Maternidade; Ensino; Período Pós-Parto.

\section{RESUMEN}

Objetivo: analizar las estrategias usadas por las enfermeras asistenciales y enfermeras docentes por una mejor posición en la maternidad del hospital-escuela de la Universidad Federal de Espírito Santo. Método: estudio de naturaleza histórico-social con abordaje cualitativo. Las fuentes primarias se constituyeron de documentos escritos, como los oficios, los memorandos, los decretos, las normas y las rutinas hospitalarias; el material fotográfico; y las declaraciones orales de siete participantes. La encuesta fue orientada por la ruta semiestructurada con cuestiones sobre la adaptación del sanatorio para hospital-escuela, los retos enfrentados y las estrategias adoptadas por la enfermería. Resultados: permitieron entender la estrecha vinculación de la maternidad con el curso de enfermería de la Universidad Federal de Espírito Santo, el que determinaba una asistencia de enfermería diferenciada, la cual 
integraba enseñanza y asistencia con una mirada más amplia y humanizada. Consideraciones finales: las acciones de las enfermeras fueron reconocidas y generaron visibilidad profesional, influenciando una nueva manera de cuidar en la maternidad.

Descriptores: Historia de la Enfermería; Cuidados de Enfermería; Maternidad; Enseñanza; Periodo Posparto.

\section{CORRESPONDING AUTHOR Antonio José de Almeida Filho E-mail: ajafilhos@gmail.com}

\section{INTRODUCTION}

The conceptions and practices related to motherhood, childbirth and postpartum are different depending on the historical moment, they were produced from the cultural and scientific discourses and practices of each moment. The technical and scientific improvements during the 20th century led the assistance to the woman and the child during childbirth and postpartum to change and become an attribution of Medicine. Thus, childbirth was transferred from households to hospitals under medical care $^{(1-2)}$. This phenomenon happened gradually, as the way society understood childbirth changed; due to being interpreted as a medical event, hospital childbirth was standardized as the safest form of care for the woman and the child, which required trained human resources to care for the binomial mother-child ${ }^{(2-4)}$.

The state of Espírito Santo (ES), Brazil, was in full economic growth by the end of the 1960 decade - with emphasis on oil and gas production. By the 1970's the state started to integrate the national development more effectively, which determined the investment in higher education in the state, when compared to the other states in the Southeast region. Given this context, on May 5, 1954, the Universidade do Espírito Santo was created, being federalized in August 22, 1965 $5^{(5-7)}$.

Institutions of higher education believed that the hospital was the ideal place to learn the health practices, as well as the rehabilitation of the health of the individual. Thus, the Universidade Federal do Espírito Santo (Ufes) started to manage the Sanatório Getúlio Vargas as a teaching hospital, seeking to strengthen the necessary infrastructure for medical training. The adequacy of this institution to incorporate its new function occurred under the Law of University Reform (RU - Lei da Reforma Universitária), no. 5.540, November 28, 1968, the objective was to establish rules for the organization and functioning of higher education in Brazilian universities. During the transition from sanatorium to teaching hospital, the institution fluctuated in its multiple functions, from being an asylum to serving as a health training space, while trying to meet two State policies: education and health ${ }^{(6-8)}$.

Technological advances and the medicalization in childbirth contributed to reduce child and maternal mortality. However, there are still large gaps to be overcome towards a quality, sensitive and safe care, this contributes to the figure of the parturient seen as a patient with no rights over her own body, violated. Often being disrespected as a human being and a citizen with full rights, causing political and social repercussions for women ${ }^{(3,9-10)}$.

The maternity ward of the teaching school of the Ufes was created while the RU was in effect, thus, consolidating the medical and hospital care of childbirth. The maternity ward was understood by the medical professors as a space to contribute in the development of the caring skills of the students; therefore, they needed to ensure the full operation of the service as a teaching institution. However, it was necessary to solve the great human resource deficit, especially in nursing, thus, many former patients from the sanatorium period went through internal courses for care ${ }^{(11)}$.

Regarding the nursing service, the hospital had two nurses in the staff: Vera Cruz Barbosa Vianna (1951-1969 administration), Head of Phthisiology, and Ivete Alves dos Santos (19681974 administration), head of nursing, as well as service attendants and nursing assistants ${ }^{(12)}$. Thus, the teaching hospital inherited professionals with different and distinct capitals.

\section{OBJECTIVE}

To analyze the strategies used by nurses and nurse professors for a better position in the maternity ward of the teaching school of the Ufes, from 1968, the year of the promulgation of the Law of University Reform and the creation of the maternity ward, to 1976, which marks the arrival of nurse professors to organize this service, due to the creation of the first nursing school in ES.

\section{METHOD}

\section{Ethical aspects}

This study was approved by the Research Ethics Committee of the Universidade Federal do Espírito Santo and authorized by the management of the Hospital Universitário Cassiano Antonio de Moraes.

\section{Theoretical-methodological framework}

We used the theoretical-philosophical framework of Pierre Bourdieu to understand the mediation between the objective and subjective dimensions of the social world, since the structuring of the practices of the nurses in the hospital space to fight for the recognition of their scientific capital were not the result from an "outside to the inside" mechanical process, neither from an autonomous process conducted by the subjects ${ }^{(13-14)}$. The concepts of habitus and field were used in this study, more directly geared towards actions regarding the "doing science" and the agents involved in this process. The concept of "scientific capital" - which serves as a type of symbolic capital - and the various uses that equally varied agents make of the sciences, are also important ${ }^{(13)}$.

\section{Type of study}

This is a social-historical study, it consists of written documents and oral statements from interviews. The written sources were official letters, memos, ordinances, rules and routines on the transition from sanatorium to teaching hospital. These documents are archived in the Memory Center of the 
Department of Nursing, and the File System (Siarg - Sistema de Arquivos) of the Ufes, and some are personal documents of some contributors to the study. The documents were selected from August 2014 to February 2016.

\section{Methodological procedures}

\section{Study scenario}

The scenario is the maternity ward of the teaching hospital of the Ufes, currently named University Hospital Cassiano Antônio de Morais (Hucam - Hospital Universitário Cassiano Antônio de Morais), in the municipality of Vitória, state of Espírito Santo, Brazil.

\section{Data Source}

We collected oral testimonies from seven nurses, the inclusion criteria adopted were: having participated in professional activity in the Ufes or in the hospital, as a teacher, nursing assistant or student, and acting directly or indirectly during the period of adaptation of the hospital and creation of the maternity ward. To select the collaborators, we searched the report and record books of the hospital and the minutes archived at the Memory Center of the Nursing Department of the Ufes.

The secondary sources were the bibliography produced on the subject. We performed active questioning procedures on the analysis of the document body, not considering them the official version. This was done to find better results. To ensure the reliability of the results we valued the documents as a set of historical research, and not the documents individually.

\section{Data collection and organization}

The interviews were performed from January to August 2015 and guided by a script with open questions on the subject. The interviews were digitally recorded and later transcribed and validated by the interviewees, after reading it and giving verbal and written authorization for the use in this research. The average duration of the interviews were two hours. To identify the interviews, we used the letter $C$ for collaborator, followed by the number corresponding to the sequential order of the interviews.

\section{Data analysis}

To support the analysis of research data, we used the three challenges described by Bourdieu ${ }^{(15)}$ : a) the illusion of transparency, defined as the danger of spontaneous understanding, as if what is real appeared clearly to the researcher; b) the risk of succumbing to the magic of the methods and techniques, forgetting the essential: the authenticity of the meanings existent in the material world and referred to the dynamic social relations; and c) the difficulty of combining theories and abstract notions with the data collected in the fieldwork.

\section{RESULTS}

The trajectory of the teaching hospital of the Ufes as a health institution was marked by transformations in its physical and organizational structure, accompanied by multiple changes in the form of care, among which we highlight in this study, the nursing care in the maternity ward. As a teaching hospital, the maternity ward service started in 1968, "an idle area of the hospital was used to install the service, with 20 beds, a delivery room and a nursery with 10 beds" to meet the educational needs of the Ufes medical school ${ }^{(12)}$.

There are few records of the maternity ward service during this period. The following excerpts from an interview register the area where the maternity ward was installed:

I started on the teaching hospital in 1966 and remember that maternity ward was created in 1968 in the physical area where the storehouse is located nowadays. (C7)

Thus, the construction of a specific physical area to care for the woman and child was a milestone in the hospital assistance as a teaching service, contributing to the care for the woman and child during pregnancy-puerperal period in the state of Espírito Santo. Furthermore, for the nurses working in that space and caring for the woman and child, this represented the achievement of an objective and symbolic goal. Since the social space is translated into the physical space, where the position of individuals or groups is expressed by the place where they are. Therefore, the existence of a social space physically objectified in the teaching hospital was an important locus for nursing to update its professional capital which was acquired on and by field practice, thus, giving it visibility.

Examining the annual report of the teaching hospital, forwarded on July 19, 1968 by its administrator, professor Nélio Espíndola, to the dean of the Ufes, Professor Alaor de Queiroz Araújo, allows us to verify the difficulties faced by administrators of the hospital to meet the requirements of the transition from sanatorium to teaching hospital. This document registers the functional difficulties and challenges to adapt to a new model of care, among which the pressing need for training human resources is highlighted, particularly in nursing.

Despite the lack of human resources in the area, the recognition of nursing as crucial to the success of the changes that the hospital was undergoing is notable. This importance can be seen in the excerpt below:

We consider the activities of the Nursing division as the backbone of the hospital infrastructure; this division is the mirror that reflects all activities of the hospital. We must give the due value to the performance of this division... during a phase of transition and transformation, when all routines had to be reviewed, adapting to the new situation very quickly ${ }^{(12)}$.

The precarious infrastructure conditions, combined with the insufficient amount of human resources evidenced the challenge and the responsibility of these two nurses during the restructuring phase of the hospital. The concern with the quality of human resources and with the deficiency or inexistence of routines and institutional standards appears in the same report quoted. This unfavorable condition demanded a complex investment from both nurses, regarding the management of staff, services and nursing care in the teaching hospital. Thus, much of the dedication of the nurses was focused on 
planning and on the training of the nursing staff for maternalchild care.

Therefore, the early years of the maternity ward were marked by important actions aimed at physical adjustments of this service and at standardization. Despite the commitment of the nurses, the excerpts of the interviews show the risks and losses in direct care for the binomial mother-child:

The hospital was very ugly, dirty... with a strong odor and few people to work. (C4)

The hospital lacked everything and there were too many constructions that occurred simultaneously to clinical procedures. (C7)

A large outbreak of infection struck the hospital in 1974. The nurse Ivete Alves dos Santos considers that it was directly related to the constructions and to the difficulty of controlling hygiene. The records considered the situation at the hospital as very serious, to the point that the administrator disclosed work orders to prevent the infection from spreading. The cause was Pseudomonas aeruginosa ${ }^{(16)}$. According to one of the collaborators, many patients were infected, and the infection was not controlled.

The case was very serious, and newspapers of the city were reporting it. Basically, all sectors of the hospital were closed. (C3)

By analyzing the admission book of the hospital, which contains the hospitalizations and their specialties, from the beginning of the decade of 1970 - involving the surgical clinic, medical services, otorhinolaryngology, ophthalmology, orthopedics, emergency, gynecology and obstetrics -, we could evidence that maternity ward recorded hospitalizations until December 11, 1974. We also noted the absence in the records until August 1st, 1976. From this we can infer that the infection outbreak may have caused the interruption of the maternity ward service at the Ufes hospital ${ }^{(17)}$.

The records and interviews evidence the commitment of the nurse, which defined the isolation of infected patients and the rigorous hygiene and access to their space as the strategy to combat the infection. We note that the prevention and the control of the infection were understood as responsibilities of the nursing division. This strategy was of great importance during that period and it achieved as much success as possible, however, it seems to have culminated in the closure of some services, including the maternity ward.

We washed the hospital... we made a collective effort, and everyone helped with buckets and brooms. (C3)

Everything was very dirty, and we had to clean up. (C7)

In 1975, a study under the management of the Department of University Affairs of the Ministry of Education and Culture (DAU/MEC - Departamento de Assuntos Universitários do Ministério da Educação e Cultura) was developed in the state of Espírito Santo. This study was led by the nurse professor Dulce Neves da Rocha from the Nursing School Anna Nery (EEAN - Escola de Enfermagem Anna Nery) of the Universidade Federal do Rio de Janeiro (UFRJ). She pointed the great lack professional nurses in the state. There was a lack of nurses on national level, which represented a threat to programs of public policies, especially those related to the Ten-Year Plan of Health for the Americas (Plano Decenal de Saúde para as Américas) of 1972 . This plan recommended a ratio of 4.5 nurses for every ten thousand inhabitants ${ }^{(18-19)}$. Regarding the teaching hospital, there was a lack of nurses, as excerpts from the report of Dulce Neves da Rocha show:

There is a total of 40 nurses working in Vitória, they are distributed as follows: 5 in the "Teaching School of the UFES"; 11 in the Hospital Foundation (Fundação Hospitalar); 18 in other government agencies and 6 in private hospitals. Of the five nurses working in the Teaching-School, only one [Ivete Oliveira] is hired by the UFES. The others are hired by a company that provides technical services. In addition to the lack of nurses, the Hospital is quantitative and qualitatively deficient in general human personnel ${ }^{(19)}$.

The arrival of Dulce Rocha to the state was heavily supported by the medicine students of the Ufes, since they realized the need for better trained nurses. We note that Dulce Rocha was born in Vitória, the capital of Espírito Santo. She had already worked in the state as a health (sanitary) visitor, she was recognized by these professionals due to her accumulated scientific capital. Dulce indicated three nurses who had recently graduated from EEAN/UFRJ to live in the city of Vitória, perform her job and create a nursing course in the state.

I was very well received, they wanted me to administrate the nursing course, but I recommended three former students of mine to come live in the state and organize it. (C4)

Thus, the restructuring of the maternity ward coincided with the activities related to the planning and organization of the first nursing school in the state of Espírito Santo. The records show that maternity ward was inaugurated on August 1st, 1976, with the direct participation of the nurse professor from Ufes, Laurinda Sebastiana dos Santos, better known as Laura.

Laura arrived as a professor of the nursing course and joined the maternity ward. She arrived on the day of the inauguration of the service and was asked to show the sector to the guests... even the Minister of Education and Culture was present. (C1)

The hospital already had five nurses in 1976: Ivete, Irmã Teresinha, Dona Edla, Valmira dos Santos and Arlete Lucas, plus 45 nursing professionals, most them being nursing attendants. Three professors joined this group, totaling eight nurses at the hospital, among them, Laura assumed the management and assistance of the maternity ward.

We note that obstetric nursing must be considered more broadly, permeating an interactive process to help the other 
in self-care, the team needed to be prepared for that. We also note that at the time there was a great concern with the complications from infections, and the transmission of knowledge was performed orally, with very few textbooks.

Nurse Laura trained everyone, she knew a lot and the medics let her teach everyone. She taught at bedside, both students and the staff. We wrote everything they needed to know and do. (C1)

Nurse Laura started doing labor, she came with the expertise and taught all students how to do it and how to take care of the mother and child during postpartum. We talked to and taught one by one. (C2)

She was the professor and her students accompanied the women at bedside. All mothers were visited at bedside by the nurse professor and her students. It was great teamwork. (C5)

The implementation of direct care for the woman and children in the context thus far (1968-1976), meant a conquest of space and position for nurses in the field of obstetrics at hospitals, also contributing to the insertion of more nurses in the hospital.

I have a great memory of the nurse teaching the mother how to breastfeed. (C1)

Laura demanded that the employees taught the mother how to breastfeed her baby. (C6)

We can conclude that nursing care in the maternity ward of the hospital was heavily influenced by the undergraduate course in nursing and provided the opportunity to engage in educational activities during childbirth and the puerperium, favoring the incorporation of specific and needed knowledge by the mother regarding her self-care and care for her child.

\section{DISCUSSION}

The training of the nursing staff was essential when considering the initial phase of the transition from a proper hospital to a learning institution, in which the hegemony of medical knowledge prevailed. The difference in capital weight of each professional or even the inexistence of it - i.e., the former patients who were trained to care - placed the nursing staff in an unfavorable position vis-à-vis the medical team. This occurs because the preservation or transformation of a structure in the social field (maternity ward) is tied to the position of the subjects in relation to one another and being classified by their capital differences ${ }^{(15)}$.

Regarding the physical restructuring of the hospital, the documents and interviews show that there was no careful planning to consider the safety of patients and professionals, since the constructions were performed concomitantly to clinical appointments; in addition, the maternity ward was affected by a serious bacterial infection by Pseudomonas aeruginosa. We note that the Pseudomonas aeruginosa are the most important agents of hospital infections, since they acquire a character of chronicity in favorable environments. Favorable conditions for the worsening of this outbreak in the hospital are created when this characteristic is associated with the historical past of the sanatorium and with the few adjustments in physical structure and the lack of human resources available to implement basic techniques of infection control ${ }^{(20)}$.

Large investments to create the nursing course of the Ufes and the reopening of the maternity ward of the teaching hospital occurred in $1976^{(18)}$. Thus, the nurse professors and academics of the area performed two functions: one related to the training of nurses, which was necessary to the state; and the other related to the good operation of the services in the teaching hospital of the Ufes, including the maternity ward, managed by Laurinda Sebastiana dos Santos, specialist in obstetric nursing.

We note that the creation of the nursing course and the arrival of nurses coincided with the reopening of maternity ${ }^{(19)}$. While the reopening marked the consolidation of the maternity ward of the teaching hospital, it also symbolized the importance of this space for student training and in this regard, since its opening the nurses understood the importance of appropriating that space for the visibility of their activities.

Thus, the reopening of the maternity ward of the hospital was materialized at a high level. Despite being young, the social and scientific capital accumulated by the professor, functioned as a set of potential resources associated to a durable network of institutional relations of shared knowledge and interrelationships. In addition to the important volume of symbolic capital she had, this nurse incorporated a distinguished professional habitus, since she had a degree from a renowned educational institution at the time, the standard official school, whose historical nature added an effect of place.

Therefore, despite being a newcomer she had a favorable position in the field, which allowed her to capitalize on symbolic gains from the impact of the social structure of her school of origin ${ }^{(21)}$. Thus, the arrival of Laura in 1976 - with scientific capital recognized and training in obstetric nursing - interested the medics who were adapting the hospital to be a teaching field.

The nurse professor considered the maternity ward service as an opportunity to put into practice the training she had during her undergraduate studies in Rio de Janeiro. Thus, the care provided by the maternity ward was in line with the public policies in force. Nursing care in the maternity ward started in 1976, meeting the Teaching and Care Integration Program (IDA - Programa de Integração Docência e Assistência). The IDA Program was one of the policies used by the Federal Government to approximate education and services. The program was presented as a proposal for health planning and education to adjust to social and technological needs, it was defined by the MEC as:

The combination of efforts in a growing process of linking Educational, Health and Services institutions adapted to the real needs of the population, to the production of knowledge and to the training of the required human resources in a certain context of practice of health and education services $^{(22)}$. 
Thus, reopening the maternity ward with a professor as the manager became viable and ratified the integration between education and care - closely related to the opening of the first Nursing School in the state -, which was the policy of the MEC, which "sought to emphasize the need for a mechanism for the regular and systematic articulation between the university hospitals and other health units, even if compulsory"(23).

The professor understood the maternity ward as a space that would contribute to the development of the nursing skills of the university students who were specializing in obstetrics. This also allowed the establishment of common work objectives between both institutions, in addition to facilitating the training and use of human resources to produce knowledge and improve the quality of care, teaching and research.

In this sense, the professor defined some competencies for nurses in the maternity ward: to identify the physical and psychological conditions of the mother, preparing her to receive her children; to provide appropriate care and support; to perform other activities relevant to the direct care of the nursing staff: hygiene (diaper change, bath and baby clothing), control of eliminations of the newborn, the umbilical stump care, monitoring of vital signs, assistance in breastfeeding and the importance of sleep and rest.

For these practices to be successful, the nurse at the maternity ward service had to present an accumulation of scientific capital capable of sustaining a new look to the woman, in this case, healthy and full of doubts. There were significant effects on the maternity ward service due to this new perspective of nurse performance in the academic field, particularly in obstetrics. This knowledge was important, since the scientific field is considered as a physical world that holds power and domination relations in which the rules were already made and in force. Power relations established within health institutions derive from knowledge and professional practices, in which certain power games occur. The nurse is responsible for organizing the service, for the guidance and supervision of personnel and for the prescription of nursing care to each user; thus, managing the service to provide qualified care for all ${ }^{(13)}$.

Using the strategy of in-service training, the nurse became an authorized spokesperson on the standardization of nursing care practices at that institution. The legitimacy of a power is built on the meritocratic/rational foundations of authority, becoming essential to accentuate the "magical dimension of the title [nurse professor], against the technical dimension that it hides"(23).

The importance of direct care to women during pregnancy and puerperium is based on the internal and external modifications of the postpartum period, in which the woman still needs supervised care that considers the complexity of factors occurring in this period. Literature is unanimous when claiming that in this phase complications that contribute to increase the coefficient of maternal mortality and morbidity may occur ${ }^{(24-33)}$.

In addition to anatomical and physiological changes that involve health risks to women during this process. The puerperium is a moment of frailty to women, in which their fears, anxieties and insecurities may surface, making hard for the woman to perform self-care and to care for her child. Given this context, nursing care went beyond the technical procedures, with the use of instruments and support so the woman could promote her own health and that of her family ${ }^{(26-27)}$.

\section{Study limitations}

The limitation of this study is the possibility of other historical documents being found in the future, despite our intense search for these materials, which would allow adjustments in the historical version presented.

\section{Contributions to the Nursing field}

The contribution of this study is highlighting the need for careful reflection regarding the direct participation of nurses in helping the woman and the child during the postpartum period, to agglutinate the efforts to reduce maternal mortality and early weaning. Historical studies on nursing in the state of Espírito Santo are rare; therefore, this research also serves as an important analytical instrument to broaden the understanding of the trajectory of maternal-child nursing in the city, state and country.

\section{FINAL CONSIDERATIONS}

Observing the history of hospitals shows us the focus on the biological model, privileging, at that time, only the reproductive dimension when considering the health of women, underestimating their needs as a woman and mother.

The initial years of the maternity ward of the teaching hospital of the Ufes (from 1968 to 1976) we identified that the nursing care went beyond the biological approach, to assist the woman during the process of adaptation to the maternal role, providing care and information on the exercise of motherhood. When teaching a mother how to sanitize the umbilical stump of her child or how to breastfeed, the nurse develops scientific care. This serves as encouragement for the mother to face her fears or difficulties, thus, minimizing the effects on her social life in the short, medium and long terms.

Thus, the planning, organizing and practicing nursing care in the maternity ward of the teaching hospital were performed alongside the creation of the nursing course of the Ufes, based on the public policies for education and health in force at the time. The contribution of nursing care in the maternity ward after the nurse professor started managing the training of the nursing team was easily perceived by all participants of this study. We could notice that the role of the nurse was extensive and well recognized during the initial phase of the service.

By recovering the memory of the care model during the initial years of the maternity ward we contributed to preserve part of the history of this institution, by filling some existing gaps in the history of nursing in this specific space. Through the history of the maternity ward of the hospital we had the opportunity to know part of the history of nursing and to honor the first nurse professor of this service.

We observed that in 1976, the nurse Laurinda from Espírito Santo, known as Laura (in memoriam), was crucial for the restructuring of the nursing service and for the recognition of the presence of the nurse in this space. The main action she 
developed added power and prestige to this professional category and, at the same time, consolidated the value of the role of the nurse as a social practice for those in society in of care, with emphasis on maternal-child care.

\section{FUNDING}

This study was funded by the Coordination for the Improvement of Higher Education Personnel - CAPES.

\section{REFERENCES}

1. Canassa NSA, Borenstein MS, Brüggemann OM, Gregório VRP. [The knowhow of midwives at Maternidade Carmela Dutra of Florianópolis - SC (1967/1994)]. Rev Bras Enferm [Internet]. 2011 [cited 2016 Oct 1];64(3):423-30. Available from: http://www. scielo.br/pdf/reben/v64n3/v64n3a03.pdf Portuguese

2. Del Priore M. Histórias e conversas de mulher. São Paulo: Planeta; 2013. 312 p.

3. Biet DB, Pires VATN. [Humanized assistance from nursing team in the course of delivery: the look of puerperal]. Revista Enfermagem Integrada - Ipatinga: Unileste [Internet]. 2015 [cited 2016 Sep 22];8(1):1289-302. Available from: http://www. unilestemg.br/enfermagemintegrada/artigo/v8/01.pdf Portuguese

4. Barbosa EMG, Sousa AAS, Vasconcelos MGF, Carvalho REFL, Oriá MOB, Rodrigues DP. [Educational technologies to encourage (self) care in postpartum women]. Rev Bras Enferm [Internet]. 2016 [cited 2016 Oct 18];69(3):545-53. Available from: http://www. scielo.br/pdf/reben/v69n3/en_0034-7167-reben-69-03-0582.pdf Portugue

5. Campista TMN, Baptista SS, Coelho MCR, Almeida Filho AJ, Xavier ML. [Panorama of the higher nursing education field in Espirito Santo's state]. Esc Anna Nery Rev Enferm [Internet]. 2009 [cited 2016 Sep 15];13(2):256-64. Available from: http://www. scielo.br/pdf/ean/v13n2/v13n2a04.pdf Portuguese

6. Redins CA. Escola de medicina da Universidade Federal do Espírito Santo: 50 anos de história. Vitória: Edufes; 2011.

7. Brasil. Lei $n^{\circ} 5.540$, de 28 de novembro de 1968. Fixa normas de organização e funcionamento do ensino superior e sua articulação com a escola média, e dá outras providências [Internet]. Diário Oficial [da] República Federativa do Brasil. Brasília, p. 10369, 29 nov. 1968 [cited 2018 Jan 31]. Seção 1. Available from: http://www2.camara.leg.br/legin/fed/lei/1960-1969/lei-554028-novembro-1968-359201-publicacaooriginal-1-pl.html

8. Borgo IA. "UFES: 40 anos de história". 2nd ed. Vitória: EDUFES; 2014.

9. Rattner D. Da saúde materno infantil ao PAISM. Tempus Actas de Saúde Colet [Internet]. 2014 [cited 2016 Sep 15];8(2):103-8. Available from: tempus.unb.br/index.php/tempus/article/download/1460/1314 Portuguese.

10. Ungerer RLS, Miranda ATC. História do alojamento conjunto. J Pediatr Rio J [Internet]. 1999 [cited 2016 Jan 3];75(1):5-10. Available from: http://www.jped.com.br/conteudo/99-75-01-05/port_print.htm

11. Franco SP, Rios ZM. A tuberculose no Espírito Santo e as ações do Estado no combate à doença. In: Franci SP, Nascimento DR, Maciel ELN. Uma história brasileira das doenças. Belo Horizonte: Fino Traço; 2013. p. 163-182.

12. Universidade Federal do Espírito Santo- UFES. Relatório de janeiro a junho de 1968. Faculdade de Medicina: Hospital das Clínicas. In: Acervo pessoal de Maria Zilma Rios. 11 p.

13. Bourdieu P. Os usos sociais da ciência: por uma sociologia clínica do campo científico. São Paulo: Editora UNESP; 2004.

14. Bourdieu P. Para uma sociologia da Ciência. Lisboa: Edições 70; 2004b.

15. Bourdieu P. Razões Práticas: sobre a teoria da ação. 6th ed. São Paulo: Papirus; 2005.

16. Universidade Federal do Espírito Santo- UFES. Ofício 1066/74 de 31 de outubro de 1974, referente a criação de um corpo médico para atender as exigências de um Hospital Escola. In: Acervo SIARG/UFES.

17. HUCAM. Livro de Admissão, 1973. Universidade Federal do Espírito Santo. Faculdade de Medicina. Hospital das Clínicas. In: Acervo pessoal de Maria Zilma Rios.

18. Coelho MCR, Gomes MLB. [The creation of Doutor Dório Silva Hospital and the configuration of positions for nurses]. Esc Anna Nery Rev Enferm [Internet]. 2008 [cited 2016 Oct 1];12(3):444-51. Available from: http://www.scielo.br/pdf/ean/v12n3/ v12n3a08.pdf Portuguese

19. Rocha DN. Relatório de Atividades junto à Universidade Federal do Espírito Santo. In: Centro de Memória de Enfermagem do Departamento de Enfermagem da Universidade Federal do Espírito Santo; 1975.

20. Silva Filho LVRF, Ferreira FA, Reis FJC, Britto MCA, Levy CE, Clark O, et al. [Pseudomonas aeruginosa infection in patients with cystic fibrosis: scientific evidence regarding clinical impact, diagnosis, and treatment]. J Bras Pneumol [Internet]. 2013 [cited 2016 Oct 17];39(4):495-512. Available from: http://www.scielo.br/pdf/jbpneu/v39n4/1806-3713-jbpneu-39-04-0495.pdf Portuguese

21. Bourdieu P. A dominação masculina. 3rd ed. São Paulo: Berthand Brasil; 2003b. 158 p.

22. Olschowsky A, Silva GB. [Teaching-welfare integration: a case study]. Rev Esc Enferm USP [Internet]. 2000 [cited 2016 Sep 10];34(2):128-37. Available from: http://www.scielo.br/pdf/reeusp/v34n2/v34n2a02.pdf Portuguese 
23. Braga E. Planejamento de saúde e integração docente-assistencial: algumas considerações. Rev Adm Públ [Internet]. 1977 [cited 2016 Sep 10];11(3):57-68. Available from: http://bibliotecadigital.fgv.br/ojs/index.php/rap/article/viewFile/6138/4754

24. Bourdieu P. O poder simbólico. 2. ed. Rio de Janeiro: Bertrand Brasil; 1998. 311 p.

25. Alkema L, Chou D, Hogan D, Zhang S, Moller AB, Gemmill A, et al. Global, regional, and national levels and trends in maternal mortality between 1990 and 2015, with scenario-based projections to 2030: a systematic analysis by the UN Maternal Mortality Estimation Inter-Agency Group. The Lancet [Internet]. 2016 [cited 2016 Oct 3]; 387(30). Available from: http://dx.doi.org/10.1016/ S0140-6736(15)00838-7

26. Cassiano AN, Holanda CSM, Costa RKS, Morais FRR, Maranhão TMO. [Nursing care to woman in immediate puerperium: a narrative description]. Rev Pesqui: Cuid Fundam [Internet]. 2015 [cited 2016 Oct 18];7(1):2061-71. Available from: http://www. seer.unirio.br/index.php/cuidadofundamental/article/download/3675/pdf_1454 Portuguese.

27. Barbosa EMG, Oliveira FDM, Guedes MVC, Monteiro ARM, Rodrigues DP, Silva LF, et al. Nursing care for one puerpera based on the theory of comfort. Rev Min Enferm [Internet]. 2014 [cited 2016 Oct 3];18(4):850-4. Available from: http://www.reme.org. br/exportar-pdf/967/en_v18n4a06.pdf

28. Ekanem El, Efiok EE, Udoh AE, Anaikot EC. Trends in postpartum maternal morbidity in Ikot Ekpene a rural community in Southern Nigeria. Open J Obstet Gynecol [Internet]. 2013 [cited 2016 Oct 18];3(6):493-9. Available from: http://file.scirp.org/pdf/ OJOG_2013072613375178.pdf

29. Quick J, Jonathan J, Langer A. Improving women's health through Universal Health Coverage. PLOS Med [Internet]. 2014 [cited 2016 Sep 20];11(1):e1001580. Available from: http://journals.plos.org/plosmedicine/article/file?id=10.1371/journal. pmed.1001580\&type $=$ printable

30. World Health Organization- WHO. Recommendations on postnatal care of the mother and newborn. WHO Library Cataloguing-in-Publication Data[Internet]. 2016 [cited 2016 Sep 20]. Geneva: WHO. Available from: http://apps.who.int/iris/ bitstream/10665/97603/1/9789241506649_eng.pdf

31. World Health Organization- WHO. The United Nations Children's Fund. Revised 1990 estimates of maternal mortality: a new approach by WHO and UNICEF: WHO/ FRH/MSM/96.11 UNICEF/PZN/96. Geneva: WHO; 1996.

32. Koblinsky M, Moyer CA, Calvert C, Campbell J, Campbell OMR, Feigl AB, et al. Quality maternity care for every woman, everywhere: a call to action. The Lancet [Internet]. 2016 [cited 2016 Oct 3]. Available from: http://www.thelancet.com/journals/ lancet/article/PIIS0140-6736(16)31333-2/fulltext

33. Yeh YC, Winsome S, Venturato L. Inside a postpartum nursing center: tradition and change. Asian Nurs Res [Internet]. 2016 [cited 2016 Oct 3];10(2):94-9. Available from: http://www.asian-nursingresearch.com/article/S1976-1317(16)30012-3/pdf 